\title{
Design and Synthesis of Resin-Conjugated Tamiflu Analogs for Affinity Chromatography ${ }^{\dagger}$
}

\author{
Yasuaki Kimura, Kenzo Yamatsugu, Motomu Kanai, ${ }^{*}$ Noriko Echigo, ${ }^{\ddagger}$ Takashi Kuzuhara, ${ }^{\star}$ and Masakatsu Shibasaki ${ }^{*}$ \\ Graduate School of Pharmaceutical Sciences, The University of Tokyo, 7-3-1 Hongo, Bunkyo-ku, Tokyo, 113-0033, Japan \\ *E-mail: mshibasa@mol.f.u-tokyo.ac.jp \\ ${ }^{\sharp}$ Faculty of Pharmaceutical Sciences, Tokushima Bunri University, Yamashiro-chi, Tokushima 770-8514, Japan \\ Received November 5, 2009, Accepted November 26, 2009
}

\begin{abstract}
Two types of resin-conjugated Tamiflu analogs were synthesized by modifying our original synthetic route of oseltamivir phosphate (Tamiflu). The prepared resins bound to influenza virus neuraminidase, the main target of Tamiflu. The resins will be useful for isolating and identifying presumed endogenous vertebrate proteins that interact with Tamiflu, which might relate to the rarely observed abnormal behavior exhibited by some influenza patients treated with Tamiflu.
\end{abstract}

Key Words: Tamiflu, Immobilization, Affinity chromatography, Abnormal behavior, Neuraminidase

\section{Introduction}

Oseltamivir phosphate (1: Tamiflu ${ }^{\circledR}$, Fig. 1) ${ }^{1}$ exhibits potent antiviral activity against influenza viruses type $\mathrm{A}$ and $\mathrm{B}$ by selectively inhibiting neuraminidase (NA), an essential enzyme for the release of virions from infected cells to expand infection. Tamiflu is a prodrug, and its active form is the corresponding carboxylic acid Ro 64-0802 (2).

Tamiflu is a very effective drug for treating influenza patients at the early stage of infection. In quite rare cases, abnormal behaviors (such as hallucinations and impulsive behavior) have been reported in Japanese patients, especially those under age of 20, after taking Tamiflu. Several research groups, including ours, are investigating whether there is any molecular-level correlation between Tamiflu medication and the abnormal behaviors. ${ }^{2}$ Based on our previous studies, ${ }^{2 \mathrm{~b}-\mathrm{d}, 2 \mathrm{f}, 21}$ we hypothesized that an endogenous human protein is specifically affected by Tamiflu (possibly, in the central nervous system). Affinity chromatography is a direct method for detecting the existence of biomolecules that interact with a particular organic molecule of interest. Here, we report the design, synthesis, and functional assessment of immobilized Tamiflu analogs on resin, which might be useful for affinity chromatography to identify possible endogenous vertebrate biomolecular targets of Tamiflu. ${ }^{2 \mathrm{~s}}$
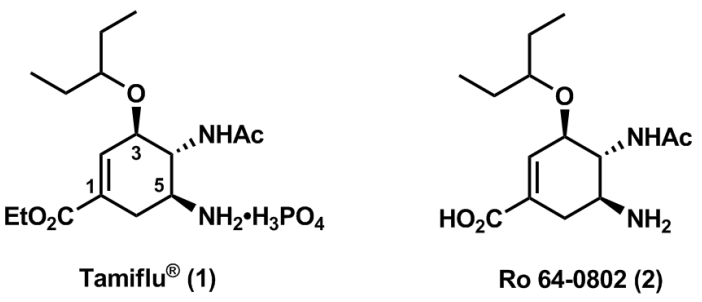

Figure 1. Structure of Tamiflu ${ }^{\circledR}$ and Ro 64-0802.

\footnotetext{
${ }^{\dagger}$ This paper is dedicated to Professor Sunggak Kim on the occasion of his honorable retirement.
}

\section{Experimental Section}

$(3 S, 4 R, 5 S)$-Allyl 4-acetamido-5-(tert-butoxycarbonylamino)-3-hydroxycyclohex-1-enecarboxylate (14). To a stirred solution of $11(1.17 \mathrm{~g}, 2.98 \mathrm{mmol})$ in allyl alcohol $(59.6 \mathrm{~mL})$, $\mathrm{K}_{2} \mathrm{CO}_{3}(2.06 \mathrm{~g}, 14.9 \mathrm{mmol})$ was added at $4{ }^{\circ} \mathrm{C}$. The resulting reaction mixture was stirred at room temperature for $2 \mathrm{~h}$. The reaction was quenched with saturated $\mathrm{NH}_{4} \mathrm{Cl}$ aqueous solution, and allyl alcohol was partially removed under reduced pressure. Aqueous layer was extracted with EtOAc, and combined organic layers were washed with brine, dried over $\mathrm{Na}_{2} \mathrm{SO}_{4}$, filtered and concentrated to afford crude $\mathbf{1 4}(1.06 \mathrm{~g})$. The crude mixture was used in the next reaction without further purification.

$(3 R, 4 R, 5 S)$-Allyl 4-acetamido-5-(tert-butoxycarbonylamino)-3-hydroxycyclohex-1-enecarboxylate (15). To a stirred solution of crude 14 (1.86 g), p-nitrobenzoic acid (1.51 g, 9.03 mmol), triphenylphosphine $(2.37 \mathrm{~g}, 9.03 \mathrm{mmol})$ in THF (90.4 $\mathrm{mL})$, and $2.2 \mathrm{M}$ solution of DEAD in toluene $(4.10 \mathrm{~mL}, 9.03$ mmol) was added at $-20{ }^{\circ} \mathrm{C}$. The resulting solution was stirred for $2 \mathrm{~h}$ at the same temperature. Then, allyl alcohol $(56.5 \mathrm{~mL})$ and DBU $(3.38 \mathrm{~mL}, 22.6 \mathrm{mmol})$ were added at $4{ }^{\circ} \mathrm{C}$ and the reaction mixture was stirred at the same temperature for $1 \mathrm{~h}$. The reaction mixture was acidified with $1 \mathrm{~N} \mathrm{HCl}$ aqueous solution, and the aqueous layer was extracted with EtOAc. Combined organic layers were washed with saturated $\mathrm{NaHCO}_{3}$ aqueous solution and brine, dried over $\mathrm{Na}_{2} \mathrm{SO}_{4}$, filtered, and concentrated to afford crude 15 (10.2 g), which was purified with silica gel column chromatography $\left(\mathrm{SiO}_{2}=500 \mathrm{~g}\right.$, Hexane/EtOAc $=1 / 2$ to $1 / 3$ to $1 / 4$ to EtOAc) to afford 15 (1.54 g, $1.41 \mathrm{mmol}, 83 \%$ over 2 steps $)$ as white powder. ${ }^{1} \mathrm{H} \mathrm{NMR}\left(\mathrm{CDCl}_{3}, 500 \mathrm{MHz}\right) \delta 7.22(\mathrm{~d}$, $J=6.3 \mathrm{~Hz}, 1 \mathrm{H}), 6.83-6.79(\mathrm{~m}, 1 \mathrm{H}), 5.94(\mathrm{~m}, 1 \mathrm{H}), 5.34-5.28(\mathrm{~m}$, $1 \mathrm{H}), 5.24-5.18(\mathrm{~m}, 1 \mathrm{H}), 5.02-4.92(\mathrm{brs}, 2 \mathrm{H}), 4.62(\mathrm{~d}, J=5.2 \mathrm{~Hz}$, $2 \mathrm{H}), 4.31-4.26$ (brs, $1 \mathrm{H}), 3.85-3.76(\mathrm{~m}, 1 \mathrm{H}), 3.76-3.70(\mathrm{~m}, 1 \mathrm{H})$, $2.80(\mathrm{dd}, J=17.8,5.2 \mathrm{~Hz}, 1 \mathrm{H}), 2.25-2.15(\mathrm{~m}, 1 \mathrm{H}), 1.98(\mathrm{~s}, 3 \mathrm{H})$, $1.42(\mathrm{~s}, 9 \mathrm{H}) ;{ }^{13} \mathrm{C} \mathrm{NMR}\left(\mathrm{CDCl}_{3}, 125 \mathrm{MHz}\right) \delta 173.6,165.6,157.7$, 139.7, 132.0, 127.7, 118.6, 80.9, 73.5, 65.7, 60.3, 48.3, 31.0, 28.4, 23.2; IR ( $\left.\mathrm{KBr}, \mathrm{cm}^{-1}\right) 3340,2978,2936,1716,1682,1529$, 1446, 1390, 1369, 1333, 1297, 1249, 1171, 1122, 1088, 1047 , 1024, 993, 934, 861, 778, 753, 738, 643; ESI-MS: $m / z$ [M+Na] 
377.1; ESI-HRMS: $m / z$ calcd for $\mathrm{C}_{17} \mathrm{H}_{26} \mathrm{~N}_{2} \mathrm{O}_{6}[\mathrm{M}+\mathrm{Na}]^{+}$: 377.1683. Found: $377.1672 ;[\alpha]_{\mathrm{D}}{ }^{25}-8.34\left(\mathrm{c}=0.76, \mathrm{CHCl}_{3}\right)$.

(1S,5S,6R)-Allyl 7-acetyl-5-(tert-butoxycarbonylamino)-7azabicyclo[4.1.0] hept-2-ene-3-carboxylate (12b). To a stirred solution of 15 (1.20 g, $3.39 \mathrm{mmol})$ in $\mathrm{CH}_{2} \mathrm{Cl}_{2}(67.8 \mathrm{~mL}), \mathrm{Me}_{2} \mathrm{PPh}$ $(967 \mu \mathrm{L}, 6.78 \mathrm{mmol}), 0.2 \mathrm{M}$ solution of $\mathrm{NEt}_{3}(3.39 \mathrm{~mL})$ and DIAD $(1.33 \mathrm{~mL}, 6.78 \mathrm{mmol})$ were added at $4{ }^{\circ} \mathrm{C}$. The resulting solution was stirred for $1 \mathrm{~h}$ at the same temperature. The reaction was quenched with saturated $\mathrm{NH}_{4} \mathrm{Cl}$ aqueous solution, and the aqueous solution was extracted with $\mathrm{CH}_{2} \mathrm{Cl}_{2}$. Combined organic layers were washed with brine, dried over $\mathrm{Na}_{2} \mathrm{SO}_{4}$, filtered, and concentrated to afford a crude mixture $(3.97 \mathrm{~g})$, which was purified with silica gel column chromatography $\left(\mathrm{SiO}_{2}=200 \mathrm{~g}\right.$, Hexane $/ \mathrm{Et}_{2} \mathrm{O}=1 / 1$ to $\left.1 / 2\right)$ to afford $\mathbf{1 2 b}(912 \mathrm{mg}, 2.71 \mathrm{mmol}$, $80 \%)$ as white amorphous. ${ }^{1} \mathrm{H} \mathrm{NMR}\left(\mathrm{CDCl}_{3}, 500 \mathrm{MHz}\right) \delta$ 7.21-7.19 (m, 1H), 5.96-5.87 (m, 1H), 5.34-5.29 (m, 1H), 5.27 (s, $1 \mathrm{H}), 5.26-5.21(\mathrm{~m}, 1 \mathrm{H}), 4.66-4.61(\mathrm{~m}, 1 \mathrm{H}), 4.57-4.50$ (brs, $1 \mathrm{H}), 4.44-4.38$ (brs, $1 \mathrm{H}), 3.14-3.06(\mathrm{~m}, 1 \mathrm{H}), 2.74$ (d, $J=17.5$, $1 \mathrm{H}), 2.50(\mathrm{~d}, J=17.5,1 \mathrm{H}), 2.13(\mathrm{~s}, 3 \mathrm{H}), 1.42(\mathrm{~s}, 9 \mathrm{H}) ;{ }^{13} \mathrm{C} \mathrm{NMR}$ $\left(\mathrm{CDCl}_{3}, 125 \mathrm{MHz}\right) \delta 181.1,165.4,154.9,134.1,131.8,130.0$, $118.4,80.0,65.6,41.9,41.0,31.8,28.2,26.6,23.1$; IR (neat, $\mathrm{cm}^{-1}$ ) 3336, 2978, 1708, 1523, 1431, 1366, 1256, 1219, 1196, 1167, 1094, 1048, 1024, 931, 834, 755; ESI-MS: $m / z[\mathrm{M}+\mathrm{Na}]^{+}$ 359.1; ESI-HRMS: $m / z$ calcd for $\mathrm{C}_{17} \mathrm{H}_{24} \mathrm{~N}_{2} \mathrm{O}_{5}[\mathrm{M}+\mathrm{Na}]^{+}$: 359.1577. Found: $359.1570 ;[\alpha]_{\mathrm{D}}{ }^{25}-20.2\left(\mathrm{c}=0.15, \mathrm{CHCl}_{3}\right)$.

5-Chloropentanal. To a stirred solution of oxalyl dichloride $(10.5 \mathrm{~mL}, 125 \mathrm{mmol})$, DMSO was added slowly at $-78^{\circ} \mathrm{C}$, and the resulting mixture was stirred at the same temperature for $15 \mathrm{~min}$. Then, 5-chloropentan-1-ol (12.0 mL, $104 \mathrm{mmol})$ was added slowly, and the reaction solution was stirred for $15 \mathrm{~min}$ at $-78{ }^{\circ} \mathrm{C}$. Triethylamine $(72.4 \mathrm{~mL})$ was added, and the reaction mixture was stirred at the same temperature for $15 \mathrm{~min}$. The reaction was warmed up to room temperature, and was quenched with $\mathrm{H}_{2} \mathrm{O}$ and saturated $\mathrm{NH}_{4} \mathrm{Cl}$ aqueous solution. The aqueous layer was extracted with $\mathrm{CH}_{2} \mathrm{Cl}_{2}$ and combined organic layers were washed with brine, dried over $\mathrm{Na}_{2} \mathrm{SO}_{4}$, filtered, and concentrated to afford crude 5-chloropentanal. The crude mixture was purified by distillation $\left(3.0 \mathrm{kPa}, 79\right.$ to $\left.83{ }^{\circ} \mathrm{C}\right)$ to afford 5 chloropentanal (7.06 g, $58.5 \mathrm{mmol}, 56 \%$ yield) as slightly yellow oil. For the spectral data of 5-chloropentanal, see: Paterson, I.; Coster, M. J.; Chen, D. Y. -K.; Aceña, J. L.; Bach, J.; Keown, L. E.; Treselmann, T. Org. Biomo. Chem. 2005, 3, 2420.

7-Chloroheptan-3-ol. To a dried flask, $\mathrm{Et}_{2} \mathrm{O}(332 \mathrm{~mL})$ and $1.0 \mathrm{M}$ solution of EtMgBr in THF was added at room temperature. Then, 5-chloropentanal $(12.0 \mathrm{~g}, 99.5 \mathrm{mmol})$ was added at $4{ }^{\circ} \mathrm{C}$, and the reaction mixture was stirred at $34^{\circ} \mathrm{C}$ for $3 \mathrm{~h}$. The reaction was quenched with water and saturated $\mathrm{NH}_{4} \mathrm{Cl}$ aqueous solution at $4{ }^{\circ} \mathrm{C}$. Aqueous layer was extracted with EtOAc, and combined organic layers were washed with brine, dried over $\mathrm{Na}_{2} \mathrm{SO}_{4}$, filtered, and concentrated to afford crude 7-chloroheptan-3-ol (14.8 g). The crude was used in the next reaction without further purification.

7-Azidoheptan-3-ol (23b). To a stirred solution of crude 7chloroheptan-3-ol (14.8 g) in DMF (117 mL), sodium azide $(25.9 \mathrm{~g})$ was added and the resulting reaction mixture was stirred for $11 \mathrm{~h}$ at $70^{\circ} \mathrm{C}$. The reaction was quenched with $\mathrm{H}_{2} \mathrm{O}$, and the aqueous layer was extracted with $\mathrm{Et}_{2} \mathrm{O}$. Combined organic layers were washed with brine, dried over $\mathrm{Na}_{2} \mathrm{SO}_{4}$, filtered, and concentrated to afford crude 7-azidoheptan-3-ol (16.7 g), which was purified with silica gel column chromatography $\left(\mathrm{SiO}_{2}=\right.$ $500 \mathrm{~g}$, Hexane/EtOAc $=4 / 1$ to 3/1) to afford 7-azidoheptan-3-ol (13.7 g, 88\% over 2 steps) as slightly yellow oil. ${ }^{1} \mathrm{H}$ NMR $\left(\mathrm{CDCl}_{3}, 500 \mathrm{MHz}\right) \delta 3.52-3.43(\mathrm{~m}, 1 \mathrm{H}), 3.24(\mathrm{t}, J=7.5 \mathrm{~Hz}, 2 \mathrm{H})$, $1.64-1.53(\mathrm{~m}, 2 \mathrm{H}), 1.52-1.38(\mathrm{~m}, 6 \mathrm{H}), 0.92-0.85(\mathrm{td}, J=7.4$, $1.7 \mathrm{~Hz}, 3 \mathrm{H}) ;{ }^{13} \mathrm{C} \mathrm{NMR}\left(\mathrm{CDCl}_{3}, 125 \mathrm{MHz}\right) \delta 72.9,51.4,36.3$, 30.2, 28.9, 22.9, 9.9; IR (neat, $\mathrm{cm}^{-1}$ ) 3376, 2937, 2874, 2096, 1638, 1460, 1350, 1251, 1126, 969, 907 ; ESI-MS: $m / z[\mathrm{M}+\mathrm{Na}]^{+}$; 180.2 .

$(3 R, 4 R, 5 S)$-Allyl 4-acetamido-3-(5-azidopentyloxy)-5-(tertbutoxycarbonylamino)cyclohex-1-enecarboxylate (16a). To a stirred solution of $\mathbf{1 2 b}(610 \mathrm{mg}, 1.81 \mathrm{mmol})$ in 5-azidopentan1-ol (23a, $6.52 \mathrm{~mL}), 4.94 \mathrm{M}$ solution of $\mathrm{BF}_{3} \cdot \mathrm{Et}_{2} \mathrm{O}$ in 23a (490 $\mu \mathrm{L}, 1.61 \mathrm{mmol}$ ) was added at $-20{ }^{\circ} \mathrm{C}$. The reaction mixture was stirred for $1 \mathrm{~h}$ at the same temperature. The reaction was diluted with EtOAc, and quenched with saturated $\mathrm{NaHCO}_{3}$ aqueous solution. The aqueous layer was extracted with EtOAc and combined organic layers were washed with brine, dried over $\mathrm{Na}_{2}-$ $\mathrm{SO}_{4}$, filtered and concentrated to afford a crude mixture (10.2 g), which was purified with silica gel column chromatography $\left(\mathrm{SiO}_{2}=500 \mathrm{~g}\right.$, Hexane/EtOAc $=5 / 2$ to $3 / 2$ to $\left.1 / 1\right)$ to afford 16a (658 mg, $1.41 \mathrm{mmol}, 78 \%$ ) as white amorphous. Remaining 23a was recovered ( $4.90 \mathrm{~mL}, 72 \%$ recovery) by the chromatography. ${ }^{1} \mathrm{H} \mathrm{NMR}\left(\mathrm{CDCl}_{3}, 500 \mathrm{MHz}\right) \delta$ 6.85-6.81 (brs, $\left.1 \mathrm{H}\right), 5.97-5.88$ (m, $1 \mathrm{H}), 5.86(\mathrm{~d}, J=5.2 \mathrm{~Hz}, 1 \mathrm{H}), 5.32(\mathrm{~d}, J=17.2 \mathrm{~Hz}, 1 \mathrm{H}), 5.24(\mathrm{~d}$, $J=10.9 \mathrm{~Hz}, 1 \mathrm{H}), 4.97(\mathrm{~d}, J=10.5 \mathrm{~Hz}, 1 \mathrm{H}), 4.64(\mathrm{~d}, J=5.7 \mathrm{~Hz}$, $2 \mathrm{H}), 4.14-4.07(\mathrm{~m}, 1 \mathrm{H}), 4.02-3.96(\mathrm{~m}, 1 \mathrm{H}), 3.81-3.72(\mathrm{~m}, 1 \mathrm{H})$, $3.65-3.57(\mathrm{~m}, 1 \mathrm{H}), 3.43-3.35(\mathrm{~m}, 1 \mathrm{H}), 3.24(\mathrm{t}, J=6.9 \mathrm{~Hz}, 2 \mathrm{H})$, $2.79(\mathrm{dd}, J=17.8,5.2 \mathrm{~Hz}, 1 \mathrm{H}), 2.30-2.20(\mathrm{~m}, 1 \mathrm{H}), 1.97(\mathrm{~s}, 1 \mathrm{H})$, $1.63-1.52(\mathrm{~m}, 1 \mathrm{H}), 1.43-1.37$ (brs, $11 \mathrm{H}) ;{ }^{13} \mathrm{C} \mathrm{NMR}\left(\mathrm{CDCl}_{3}, 125\right.$ $\mathrm{MHz}) \delta 171.4,165.7,156.8,137.9,132.3,130.3,118.9,80.3$, 78.4, 68.7, 66.1, 54.0, 51.7, 49.5, 31.7, 29.8, 29.0, 28.7, 23.8, 23.7; IR (KBr, cm $\left.{ }^{-1}\right) 3584,3319,2936,2347,2096,1719,1686$, 1658, 1530, 1450, 1367, 1296, 1241, 1173, 1094, 1045, 1019, 930, 680; ESI-MS: $m / z[\mathrm{M}+\mathrm{Na}]^{+}$488.3; ESI-HRMS: $m / z$ calcd for $\mathrm{C}_{22} \mathrm{H}_{35} \mathrm{~N}_{5} \mathrm{O}_{6}[\mathrm{M}+\mathrm{Na}]^{+}:$488.2480. Found: 488.2478; $[\alpha]_{\mathrm{D}}{ }^{25}$ $-80.7\left(\mathrm{c}=0.54, \mathrm{CHCl}_{3}\right)$.

$(3 R, 4 R, 5 S)$-Allyl 4-acetamido-3-(7-azidoheptan-3-yloxy)-5(tert-butoxycarbonylamino)cyclohex-1-enecarboxylate (16b). To a stirred solution of $\mathbf{1 2 b}(425 \mathrm{mg}, 1.29 \mathrm{mmol})$ in 7-azidoheptan-3-ol (23b, 5.65 mL), 4.94 M solution of $\mathrm{BF}_{3} \cdot \mathrm{Et}_{2} \mathrm{O}$ in $\mathbf{2 3 b}$ $(669 \mu \mathrm{L}, 1.94 \mathrm{mmol})$ was added at $-20{ }^{\circ} \mathrm{C}$. The reaction mixture was stirred for $1 \mathrm{~h}$ at the same temperature. The reaction was diluted with EtOAc, and quenched with saturated $\mathrm{NaHCO}_{3}$ aqueous solution. The aqueous layer was extracted with EtOAc, and combined organic layers were washed with brine, dried over $\mathrm{Na}_{2} \mathrm{SO}_{4}$, filtered and concentrated to afford crude $\mathbf{1 6 b}(6.50 \mathrm{~g})$, which was purified with silica gel column chromatography $\left(\mathrm{SiO}_{2}=330 \mathrm{~g}, \mathrm{CH}_{2} \mathrm{Cl}_{2} / \mathrm{EtOAc}=4 / 1\right.$ to $3 / 1$ to $\left.2 / 1\right)$ to afford $\mathbf{1 6 b}$ (324 mg, ca. 1:1 mixture of diastereomers, $657 \mu \mathrm{mol}, 51 \%$ ) as white amorphous. Remaining $\mathbf{2 3 b}$ was recovered $(5.34 \mathrm{~mL}, 91 \%$ recovery) by the chromatography.

$(3 R, 4 R, 5 S)$-Allyl 5-(( $9 H$-fluoren-9-yl)methoxy)carbonylamino)-4-acetamido-3-(5-azidopentyloxy)cyclohex-1-enecar boxylate (17a). To a stirred solution of $16 \mathbf{a}(9.70 \mathrm{mg}, 20.8 \mu \mathrm{mol})$ in $\mathrm{CH}_{2} \mathrm{Cl}_{2}(333 \mu \mathrm{L})$, TFA $(83.2 \mu \mathrm{L})$ was added and the mixture was stirred for $30 \mathrm{~min}$ at room temperature. Volatiles were re- 
moved under reduced pressure to afford a crude mixture, to which $\mathrm{CH}_{2} \mathrm{Cl}_{2}$ and saturated $\mathrm{NaHCO}_{3}$ aqueous solution were added. The aqueous layer was extracted with $\mathrm{CH}_{2} \mathrm{Cl}_{2}$, and combined organic layers were washed with brine, dried over $\mathrm{Na}_{2}-$ $\mathrm{SO}_{4}$, filtered and concentrated to give a crude mixture $(8.30 \mathrm{mg})$. To a stirred solution of the crude mixture in dioxane $(208 \mu \mathrm{L})$ and $\mathrm{H}_{2} \mathrm{O}(208 \mu \mathrm{L}), \mathrm{NaHCO}_{3}(4.20 \mathrm{mg}, 50.0 \mu \mathrm{mol})$ and $\mathrm{FmocCl}$ $(6.47 \mathrm{mg}, 25.0 \mu \mathrm{mol})$ were added at room temperature. After stirring for $35 \mathrm{~h}$, the reaction was quenched with saturated $\mathrm{NH}_{4} \mathrm{Cl}$ aqueous solution. The aqueous solution was extracted with EtOAc, and combined organic layers were washed with brine, dried over $\mathrm{Na}_{2} \mathrm{SO}_{4}$, filtered, and concentrated to afford crude $17 \mathbf{a}(14.7 \mathrm{mg})$, which was purified with silica gel column chromatography $\left(\mathrm{SiO}_{2}=600 \mathrm{mg}\right.$, Hexane/EtOAc $=3 / 1$ to $\left.1 / 1\right)$ to afford 17a $(9.80 \mathrm{mg}, 16.7 \mu \mathrm{mol}, 80 \%$ yield) as white powder. ${ }^{1} \mathrm{H} \mathrm{NMR}\left(\mathrm{CDCl}_{3}, 500 \mathrm{MHz}\right) \delta 7.73(\mathrm{~d}, J=7.5 \mathrm{~Hz}, 2 \mathrm{H}), 7.54(\mathrm{~d}$, $J=7.5 \mathrm{~Hz}, 2 \mathrm{H}), 7.37(\mathrm{dd}, J=7.5,7.5 \mathrm{~Hz}, 2 \mathrm{H}), 7.29$ (dd, $J=7.5$, $7.5 \mathrm{~Hz}, 2 \mathrm{H}), 6.86(\mathrm{~s}, 1 \mathrm{H}), 5.98-5.88(\mathrm{~m}, 1 \mathrm{H}), 5.72(\mathrm{~d}, J=10.8$ $\mathrm{Hz}, 1 \mathrm{H}), 5.61(\mathrm{~d}, J=9.2 \mathrm{~Hz}, 1 \mathrm{H}), 5.34(\mathrm{~d}, J=17.2 \mathrm{~Hz}, 1 \mathrm{H})$, $5.24(\mathrm{~d}, J=10.3 \mathrm{~Hz}, 1 \mathrm{H}), 4.65(\mathrm{~d}, J=5.8 \mathrm{~Hz}, 1 \mathrm{H}), 4.34-4.26$ $(\mathrm{m}, 2 \mathrm{H}), 4.20-4.14(\mathrm{~m}, 2 \mathrm{H}), 4.04(\mathrm{~d}, J=8.6 \mathrm{~Hz}, 1 \mathrm{H}), 3.91-3.80$ $(\mathrm{m}, 1 \mathrm{H}), 3.45-3.37(\mathrm{~m}, 1 \mathrm{H}), 3.24(\mathrm{t}, J=6.9 \mathrm{~Hz}, 1 \mathrm{H}), 2.85(\mathrm{dd}$, $J=18.1,5.2 \mathrm{~Hz}, 1 \mathrm{H}), 2.34(\mathrm{dd}, J=18.1,9.7 \mathrm{~Hz}, 1 \mathrm{H}), 1.94(\mathrm{~s}$, $1 \mathrm{H}), 1.62-1.52(\mathrm{~m}, 4 \mathrm{H}), 1.46-1.36(\mathrm{~m}, 2 \mathrm{H}) ;{ }^{13} \mathrm{C} \mathrm{NMR}\left(\mathrm{CDCl}_{3}\right.$, $125 \mathrm{MHz}) \delta 171.6,165.4,156.8,143.91,143.87,141.4,137.0$, 132.0, 130.4, 127.9, 127.2, 125.3, 125.2, 120.2, 120.1, 118.9, $68.3,67.3,65.9,52.8,51.5,50.4,47.2,31.5,29.6,28.8,23.5$, 23.4; IR ( $\left.\mathrm{KBr}, \mathrm{cm}^{-1}\right) 3290,3071,2941,2865,2097,1690,1654$, 1557, 1449, 1373, 1231, 1149, 1086, 934, 868, 759, 738, 647; ESI-MS: $m / z$ [M+Na $]^{+} 610.4$; ESI-HRMS: $m / z$ calcd for $\mathrm{C}_{32} \mathrm{H}_{37}$ $\mathrm{N}_{5} \mathrm{O}_{6}[\mathrm{M}+\mathrm{Na}]^{+}: 610.2636$. Found: $610.2649 ;[\alpha]_{\mathrm{D}}{ }^{25}-34.8(\mathrm{c}=$ $\left.0.38, \mathrm{CHCl}_{3}\right)$.

(3R,4R,5S)-Allyl 5-(((9H-fluoren-9-yl)methoxy)carbonylamino)-4-acetamido-3-(7-azidoheptan-3-yloxy)cyclohex-1enecarboxylate (17b). To a stirred solution of $\mathbf{1 6 b}(324 \mathrm{mg}$, $656 \mu \mathrm{mol})$ in $\mathrm{CH}_{2} \mathrm{Cl}_{2}(13.1 \mathrm{~mL})$, TFA $(2.63 \mathrm{~mL})$ was added, and the mixture was stirred for $4 \mathrm{~h}$ at room temperature. Volatiles were removed under reduced pressure to afford a crude mixture, to which $\mathrm{CH}_{2} \mathrm{Cl}_{2}$ and saturated $\mathrm{NaHCO}_{3}$ aqueous solution was added. The aqueous layer was extracted with $\mathrm{CH}_{2} \mathrm{Cl}_{2}$, and combined organic layers were washed with brine, dried over $\mathrm{Na}_{2}-$ $\mathrm{SO}_{4}$, filtered and concentrated to give a crude mixture $(282 \mathrm{mg})$. To a stirred solution of the crude mixture in dioxane $(6.56 \mathrm{~mL})$ and $\mathrm{H}_{2} \mathrm{O}(6.56 \mathrm{~mL}), \mathrm{NaHCO}_{3}(133 \mathrm{mg}, 1.57 \mathrm{~mol})$ and $\mathrm{FmocCl}$ $(204 \mathrm{mg}, 787 \mu \mathrm{mol})$ were added at room temperature. After stirring for $11 \mathrm{~h}$, the reaction was quenched with saturated $\mathrm{NH}_{4} \mathrm{Cl}$ aqueous solution, and the aqueous solution was extracted with EtOAc. Combined organic layers were washed with brine, dried over $\mathrm{Na}_{2} \mathrm{SO}_{4}$, filtered, and concentrated to afford crude $\mathbf{1 7 b}$ $(560 \mathrm{mg})$, which was purified with silica gel column chromatography $\left(\mathrm{SiO}_{2}=20 \mathrm{~g}, \mathrm{CH}_{2} \mathrm{Cl}_{2}\right.$ to $\left.\mathrm{CH}_{2} \mathrm{Cl}_{2} / \mathrm{MeOH}=80 / 1\right)$ to afford 17b (320 mg, $520 \mu \mathrm{mol}, \mathrm{ca} .1: 1 \mathrm{mixture}$ of diastereomers, $79 \%$ yield) as white powder.

(3R,4R,5S)-5-(((9H-Fluoren-9-yl)methoxy)carbonylamino)4-acetamido-3-(5-azidopentyloxy)cyclohex-1-enecarboxylic acid (19a). To a stirred solution of $17 \mathbf{a}(200 \mathrm{mg}, 340 \mu \mathrm{mol})$ in THF (6.80 mL), $\mathrm{Pd}\left(\mathrm{PPh}_{3}\right)_{4}(39.3 \mathrm{mg}, 34.0 \mu \mathrm{mol})$ and $N$-methylaniline $(368 \mu \mathrm{L}, 3.40 \mathrm{mmol})$ were added at room temperature.
After the reaction mixture was degassed (freeze/pump/thaw, 3 times), the reaction was stirred for $2 \mathrm{~h}$ at room temperature. The reaction mixture was diluted with EtOAc, and $1 \mathrm{~N} \mathrm{HCl}$ aqueous solution was added at $0{ }^{\circ} \mathrm{C}$. The aqueous layer was extracted with EtOAc, and combined organic layers were washed with brine, dried over $\mathrm{Na}_{2} \mathrm{SO}_{4}$, and concentrated to afford crude 19a (229 mg), which was purified with silica gel column chromatography $\left(\mathrm{SiO}_{2}=11 \mathrm{~g}, \mathrm{CH}_{2} \mathrm{Cl}_{2} / \mathrm{MeOH}=50 / 1\right.$ to $25 / 1$ to $10 / 1$ to $5 / 1)$ to afford $19 \mathrm{a}(171 \mathrm{mg}, 312 \mu \mathrm{mol}, 91 \%$ yield) as white powder. ${ }^{1} \mathrm{H}$ NMR (DMSO- $\left.d_{6}, 500 \mathrm{MHz}\right) \delta 7.90(\mathrm{~d}, J=7.6 \mathrm{~Hz}$, $2 \mathrm{H}), 7.81(\mathrm{~d}, J=9.2 \mathrm{~Hz}, 1 \mathrm{H}), 7.66(\mathrm{~d}, J=6.5 \mathrm{~Hz}, 2 \mathrm{H}), 7.44-7.38$ $(\mathrm{m}, 2 \mathrm{H}), 7.35-7.28(\mathrm{~m}, 2 \mathrm{H}), 7.17(\mathrm{~d}, J=9.2 \mathrm{~Hz}, 1 \mathrm{H}), 6.68-6.64$ (brs, $1 \mathrm{H}), 4.37-4.30(\mathrm{~m}, 1 \mathrm{H}), 4.23-4.14(\mathrm{~m}, 2 \mathrm{H}), 4.08(\mathrm{~d}, J=8.3$ $\mathrm{Hz}, 1 \mathrm{H}), 3.85$ (ddd, $J=9.2,8.3,8.3 \mathrm{~Hz}, 1 \mathrm{H}), 3.69-3.60(\mathrm{~m}, 1 \mathrm{H})$, 3.60-3.54 (m, 1H), 3.45-3.38 (m, 1H), 3.34-3.27 (t, $J=6.7 \mathrm{~Hz}$, $2 \mathrm{H}), 2.56-2.52(\mathrm{~m}, 1 \mathrm{H}), 2.32-2.23(\mathrm{~m}, 1 \mathrm{H}), 1.74(\mathrm{~s}, 1 \mathrm{H}), 1.55-$ $1.43(\mathrm{~m}, 4 \mathrm{H}), 1.38-1.28(\mathrm{~m}, 2 \mathrm{H}) ;{ }^{13} \mathrm{C}$ NMR (DMSO-d 6,125 MHz) $\delta 169.6,167.1,155.9,143.9,147.7,140.7,140.6,136.5$, $130.0127 .6,127.0,125.2,125.0,120.08,120.06,76.7,68.2$, $65.6,52.9,50.6,49.7,46.7,30.6,28.9,27.9,22.75,22.72$; IR $\left(\mathrm{KBr}, \mathrm{cm}^{-1}\right) 3290,3068,2941,2865,2097,1698,1543,1449$, 1373, 1287, 1151, 1086, 1033, 866, 760, 740; ESI-MS: $m / z$ [M+ $\mathrm{Na}]^{+}$570.3; ESI-HRMS: $m / z$ calcd for $\mathrm{C}_{29} \mathrm{H}_{33} \mathrm{~N}_{5} \mathrm{O}_{6}[\mathrm{M}+\mathrm{Na}]^{+}$: 570.2323. Found: 570.2335; $[\alpha]_{\mathrm{D}}{ }^{25}-44.7\left(\mathrm{c}=0.55, \mathrm{CH}_{3} \mathrm{OH}\right)$.

(3R,4R,5S)-5-(((9H-Fluoren-9-yl)methoxy)carbonylamino)4-acetamido-3-(7-azidoheptan-3-yloxy)cyclohex-1-enecarboxylic acid (19b). To a stirred solution of $17 \mathbf{b}(320 \mathrm{mg}, 520$ $\mu \mathrm{mol})$ in THF $(10.4 \mathrm{~mL}), \mathrm{Pd}\left(\mathrm{PPh}_{3}\right)_{4}(60.1 \mathrm{mg}, 52.0 \mu \mathrm{mol})$ and $N$ methylaniline $(563 \mu \mathrm{L}, 5.20 \mathrm{mmol})$ were added at room temperature. After the reaction mixture was degassed (freeze/pump/ thaw, 3 times), the mixture was stirred for $30 \mathrm{~min}$ at room temperature. The reaction mixture was diluted with EtOAc, and $1 \mathrm{~N}$ $\mathrm{HCl}$ aqueous solution was added at $0{ }^{\circ} \mathrm{C}$. The aqueous layer was extracted with EtOAc, and combined organic layers were washed with brine, dried over $\mathrm{Na}_{2} \mathrm{SO}_{4}$, and concentrated to afford crude 19a (370 mg), which was purified with silica gel column chromatography $\left(\mathrm{SiO}_{2}=16 \mathrm{~g}, \mathrm{CH}_{2} \mathrm{Cl}_{2} / \mathrm{MeOH}=50 / 1\right.$ to $10 / 1$ to $5 / 1)$ to afford 19a (247 mg, ca. 1:1 mixture of diastereomers, 429 $\mu \mathrm{mol}, 83 \%$ yield) as white powder.

$(3 R, 4 R, 5 S)-5-(((9 H-F l u o r e n-9-y l) m e t h o x y)$ carbonylamino)4-acetamido-3-(5-aminopentyloxy)cyclohex-1-enecarboxylic acid (20a). To a stirred mixture of 19a (42.5 mg, $77.7 \mu \mathrm{mol})$ and zinc pre-activated with 1,2-dibromoethane ${ }^{3}(1.22 \mathrm{~g}, 18.6 \mathrm{mmol})$ in $\mathrm{EtOH}(1.24 \mathrm{~mL})$, TFA $(311 \mu \mathrm{L})$ was added and the reaction mixture was stirred for $1.5 \mathrm{~h}$ at room temperature. The reaction mixture was filtered to remove an excess amount of zinc, and the mother liquid was concentrated to afford crude $\mathbf{2 0 a}(598 \mathrm{mg})$ as colorless oil. The yield of $\mathbf{2 0 a}$ was $95 \%$ based on crude NMR analysis. The crude was used in the next reaction without further purification.

$(3 R, 4 R, 5 S)-5-(((9 H-F l u o r e n-9-y l)$ methoxy)carbonylamino)4-acetamido-3-(7-aminoheptan-3-yloxy)cyclohex-1-enecarboxylic acid (20b). To a stirred mixture of 19b (245 mg, 426 $\mu \mathrm{mol})$ and zinc pre-activated with 1,2-dibromoethane ${ }^{3}(6.00 \mathrm{~g}$, $102 \mathrm{mmol})$ in EtOH $(6.82 \mathrm{~mL})$, TFA $(1.70 \mathrm{~mL})$ was added, and the reaction mixture was stirred for $1 \mathrm{~h}$ at room temperature. The reaction mixture was filtered to remove an excess amount of zinc, and the mother liquid was concentrated to afford crude 
20b (2.64 g) as colorless oil. The yield of 20a was $99 \%$ based on crude NMR analysis. The crude was used in the next reaction without further purification.

Tamiflu analog on resin (3a). To a plastic tube, crude 20a (3.57 mg, $6.85 \mu \mathrm{mol})$ in $\mathrm{MeOH}, \mathrm{MeOH}(12 \mathrm{~mL}), \mathrm{NEt}_{3}(50 \mu \mathrm{L})$ and Affi-Gel $10(2.74 \mathrm{~mL}, 41.1 \mu \mathrm{mol}$ as the activated ester residues) were added, and the reaction mixture was shaken at room temperature for $1 \mathrm{~h}$. The resin was filtered and washed with $\mathrm{MeOH}$. The resulting mother liquid was concentrated to afford a crude mixture and the amount of 20a in the crude was quantified $(2.71 \mu \mathrm{mol})$ with quantitative NMR analysis. To another plastic tube, the resin, piperidine $(2.74 \mathrm{~mL})$, and DMF $(2.74 \mathrm{~mL})$ were added, and the resulting reaction mixture was shaken at room temperature for $24 \mathrm{~h}$. The resin was filtered and washed with $\mathrm{Et}_{2} \mathrm{O}$. To the resulting mother liquid, $\mathrm{H}_{2} \mathrm{O}$ was added, and the aqueous layer was extracted with $\mathrm{Et}_{2} \mathrm{O}$. Combined organic layers were concentrated to afford a crude mixture, and the amount of 22 in the crude was quantified $(4.10 \mu \mathrm{mol})$ by qualitative NMR analysis. The resin was then washed with $\mathrm{MeOH}, 5 \%$ AcOH aqueous solution and $\mathrm{H}_{2} \mathrm{O}$. Based on the quantitative NMR analysis, the loading of Tamiflu core on resin was determined to be $1.50 \mu \mathrm{mol} / \mathrm{mL}$ (undried resin).

Tamiflu analog on resin (3b). To a plastic tube, crude $\mathbf{2 0 b}$ (6.70 mg, $12.2 \mu \mathrm{mol})$ in $\mathrm{MeOH}, \mathrm{MeOH}(5 \mathrm{~mL}), \mathrm{NEt}_{3}(100 \mu \mathrm{L})$ and Affi-Gel $10(3.02 \mathrm{~mL} .45 .6 \mu \mathrm{mol}$ as the activated ester residues) were added and the reaction mixture was shaken at room temperature for $8 \mathrm{~h}$. The resin was filtered and washed with $\mathrm{MeOH}$. The mother liquid was concentrated to afford a crude mixture, and the amount of $\mathbf{2 0 b}$ in the crude was quantified $(4.48 \mu \mathrm{mol})$ with quantitative NMR analysis. To another plastic tube, the resin, piperidine $(1.50 \mathrm{~mL})$, and DMF $(1.50 \mathrm{~mL})$ were added, and the resulting reaction mixture was shaken at room temperature for $24 \mathrm{~h}$. The resin was filtered and washed with $\mathrm{Et}_{2} \mathrm{O}$. To the resulting mother liquid, $\mathrm{H}_{2} \mathrm{O}$ was added, and the aqueous layer was extracted with $\mathrm{Et}_{2} \mathrm{O}$. Combined organic layers were concentrated to afford a crude mixture. The amount of 22 in the crude was quantified $(7.60 \mu \mathrm{mol})$ by qualitative NMR analysis. The resin was then washed with $\mathrm{MeOH}, 5 \% \mathrm{AcOH}$ aqueous solution and $\mathrm{H}_{2} \mathrm{O}$. Based on the quantitative NMR analysis, the loading of Tamiflu core on resin was determined to be $2.52 \mu \mathrm{mol} / \mathrm{mL}$ (undried resin).

Assessment of the binding affinity of synthesized conjugates 3a and 3b. Recombinant Influenza A virus H1N1 neuraminidase (rvH1N1NA, $0.5 \mu \mathrm{g}$, purchased from R\&D Systems, Inc.) and $50 \mu \mathrm{L}$ of each $40 \%$ resin (3a or $\mathbf{3 b}$ or control resin) were mixed and incubated in $250 \mu \mathrm{L}$ Tamiflu binding buffer [ $50 \mathrm{mM}$ Tris$\mathrm{HCl}, 100 \mathrm{mM} \mathrm{NaCl}, 5 \mathrm{mM} \mathrm{CaCl}_{2}, 0.01 \%$ NP-40 (Nonidet P-40); $\mathrm{pH}$ 7.5] at $4{ }^{\circ} \mathrm{C}$ for $2 \mathrm{~h}$. After washing the resin five times with Tamiflu binding buffer, the resin was resuspended in SDS-sample buffer [containing 3.3\% SDS (sodium dodecyl sulfate), 2.5\% 2-mercaptoethanol] and was boiled for 2 - $3 \mathrm{~min}$. The supernatant was subjected to electrophoresis on two SDS-10\% polyacrylamide gels. One gel was visualized silver staining (A). The other gel was transferred to PVDF (polyvinylidene difluoride) membrane $30 \mathrm{~V}$, overnight. The PVDF membrane was blocked in the blocking buffer [ $5 \%$ skim milk, $40 \mathrm{mM}$ sodium phosphate buffer; $\mathrm{pH}$ 7.2] for $1 \mathrm{~h}$ at room temperature, and incubated with sheep anti-rvH1N1NA antibody (diluted 1:1000, R\&D Systems,
Inc.) in the buffer [0.01\% Tween $20,20 \mathrm{mM}$ sodium phosphate buffer; $\mathrm{pH}$ 7.2] for $1 \mathrm{~h}$ at room temperature. After the membrane was washed for $5 \mathrm{~min} \times 4$ times in the same buffer, it was treated with peroxidase conjugated donkey anti-sheep IgG antibody (diluted 1:10000, Chemicon) in the blocking buffer for $1 \mathrm{~h}$ at room temperature. The membrane was washed for $10 \mathrm{~min} \times 6$ times, and then it was subjected to ECL (Enzymatic Chemiluminescence) amplification with Supersignal ${ }^{\mathbb{R}}$ West Pico Chemiluminescent substrate (Pierce Protein Research). rvH1N1NA was detected in the bound fraction at the expected position on the gel when rvH1N1NA was mixed with resin-conjugated Tamiflu analogs 3a and 3b (Fig. 3, lanes 5 and 7). rvH1N1NA was not detected in other lanes on the gel.

\section{Results and Discussions}

Our design of immobilized Tamiflu analogs is based on the assumption that the binding mode of $\mathbf{2}$ to potential target vertebrate proteins is similar to that for binding virus NA. Analysis of the X-ray crystal structures of the NA-2 complex ${ }^{1 \mathrm{a}, 4}$ and the reported structure-activity relationship data ${ }^{\text {la }}$ led to the identification of the following two major bases for the molecular design: (1) modifications of the $\mathrm{C} 3$ pentyloxy part do not completely disrupt the binding to NA, although modifications of the $\mathrm{Cl}$ carboxyl group, the $\mathrm{C} 4$ acetamide moiety, and the $\mathrm{C} 5$ amino functionality do disrupt binding to NA. Therefore, the $\mathrm{C} 3$ ether part was selected to connect the oseltamivir core to the resin. (2) The binding site of $\mathbf{2}$ is positioned close to the surface of NA, ${ }^{4 a}$ suggesting that a relatively short spacer (five carbons) between the oseltamivir core and the resin would be sufficient for binding to NA. Based on these considerations, we designed 3 immobilized to Affi-Gel $10^{\circledR}$ resin (Fig. 2). Furthermore, the structureactivity relationship data ${ }^{1 \mathrm{a}}$ also suggested that the chirality of the spacer moiety (i.e. chirality at the carbon with asterisk of $\mathbf{3 b}$ ) does not affect the binding affinity of Tamiflu derivatives to NA. Hence, we decided to synthesize $\mathbf{3 b}$ as a mixture of diasteromers.

The synthesis of $\mathbf{3}$ should be straightforward by extending the previously established synthetic route of Tamiflu. ${ }^{1 \mathrm{n}}$ Briefly, this route involves an asymmetric Diels-Alder-type reaction between siloxy diene 4 and dimethyl fumarate (5) catalyzed by a barium-FujiCAPO (6, CAPO = CAtechol Phosphine Oxide $)$ complex, Curtius rearrangement, and Pd-catalyzed allylic substitution with MAC reagent 9 (MAC = Masked Acyl Cyanide)

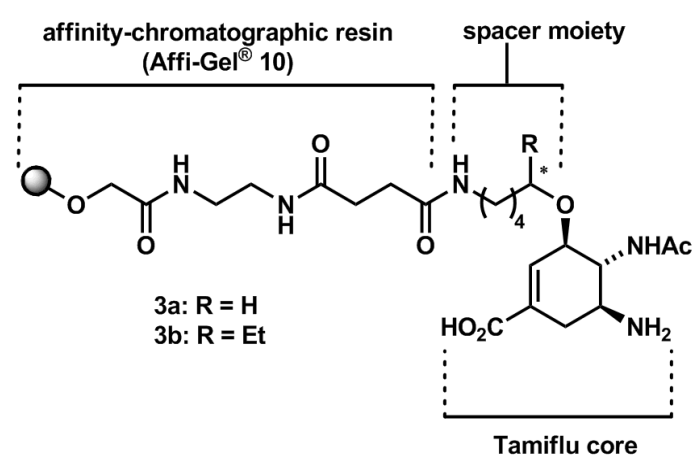

Figure 2. The structure of the designed resin-conjugated Tamiflu analogs. 

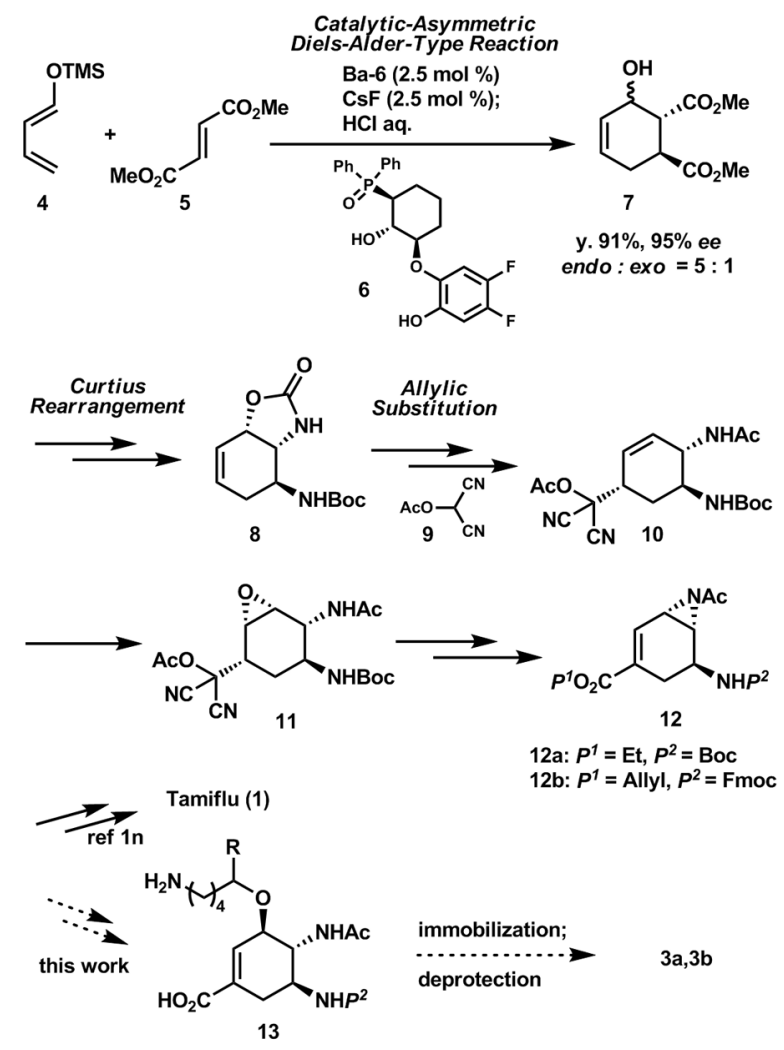

Scheme 1. Brief summary of the previously developed synthetic route of Tamiflu (1) and synthetic route for the resin-conjugated Tamiflu analogs $\mathbf{3 a}, \mathbf{3 b}$

as key steps (Scheme 1). Introduction of 5-aminopentan-1-ol (or its equivalent) through a ring-opening reaction of an aziridine (12) would produce 13 containing an oseltamivir core with a spacer, which should be immobilized to Affi-Gel $10^{\circledR}$ via simple amide formation. The proper selection of the protecting groups at the $\mathrm{C} 1$ carboxylic acid moiety $\left(P^{l}\right)$ and the $\mathrm{C} 5$ amino group $\left(P^{2}\right)$ is crucial for the success of the synthesis. An Fmoc group was selected as $P^{2}$ because it can be cleaved under mild conditions without affecting the agarose skeleton of the resin. Moreover, the amount of immobilized oseltamivir core can be quantified based on the amount of released fluorenyl derivative (22). $P^{l}$ should be removed in the presence of the Fmoc group, and therefore we selected an allyl group for $P^{l}(\mathbf{1 2 b})$.

Our synthesis of $\mathbf{3}$ started from known epoxide 11, which was synthesized following the previously developed procedures shown in Scheme 1. ${ }^{1 \mathrm{n}}$ Treatment of $\mathbf{1 1}$ with potassium carbonate in allyl alcohol yielded allyl ester $\mathbf{1 4}$ via alcoholysis of the acetoxydicyanomethyl moiety and the subsequent eliminative epoxide opening (Scheme 2). Inversion of $\alpha$-alcohol 14 to $\beta$-isomer 15 was realized via $\mathrm{S}_{\mathrm{N}} 2$ attack of $p$-nitrobenzoic acid under Mitsunobu conditions, followed by selective cleavage of the $p$-nitrobenzoate. DBU was used as a base in the alcoholysis step because previously utilized $\mathrm{LiOH} \cdot \mathrm{H}_{2} \mathrm{O}^{\text {1n }}$ was not effective due to its low solubility in allyl alcohol. Mitsunobu aziridine formation using dimethylphenyl phosphine and DIAD in the presence of a catalytic amount of triethylamine ${ }^{\mathrm{ln}}$ afforded $\mathbf{1 2 b}$ in high yield. Next, the aziridine opening reaction with 5-azidopentan1-ol $\mathrm{l}^{5}$ required some optimization. The major byproduct of this reaction was oxazoline $\mathbf{2 4}$ which was derived via migration of the aziridine before the addition of the azido alcohol. To facilitate the desired intermolecular reaction, we used an excess amount of azido alcohol. ${ }^{6}$ Using 0.88 eq of $\mathrm{BF}_{3} \cdot \mathrm{Et}_{2} \mathrm{O}$ and $30 \mathrm{eq}$ of 23a, ether 16a was obtained in $78 \%$ yield. The excess azido alcohol 23a was recovered for reuse in more than $70 \%$ yield after chromatographic separation. 16b was synthesized following almost the same procedure albeit in lower yield (51\%), reflecting the lower nucleophilicity of secondary alcohol $\mathbf{2 3 b}$ than $\mathbf{2 3 a}$ due to increased steric hindrance.

With ethers $\mathbf{1 6}$ in hand, the next key intermediate was amino acids 20. Conversion of the protecting group at the $\mathrm{C} 5$ amino group from Boc to Fmoc, reduction of the azide group, and cleavage of $\mathrm{C} 1$ allyl ester were required, but the order of the three transformations had to be optimized. After converting the protecting group from Boc to Fmoc, which produced 17, reduction of the azide group was attempted (Table 1). Staudinger reduction using $\mathrm{PPh}_{3}$ or $n-\mathrm{Bu}_{3} \mathrm{P}$ did not afford target compound 18 at all (entries 1 and 2). Reductions with Lindlar catalyst (entries 3 and 4$)$ or other reductants $\left(\mathrm{NaBH}_{4} / \mathrm{CoCl}_{2}\right.$ or $\left.\mathrm{SnCl}_{2}\right)$ were not successful either (entries 5 and 6). On the other hand, reduction proceeded in moderate yield in $\mathrm{AcOH}$ solvent using zinc powder pre-activated with $1 \mathrm{M} \mathrm{HCl}$ (entry 7). Subsequent optimization regarding the method of zinc activation, the proton source, and the solvent led us to identify the optimum conditions (entry 8): zinc powder pre-activated with dibromoethane and
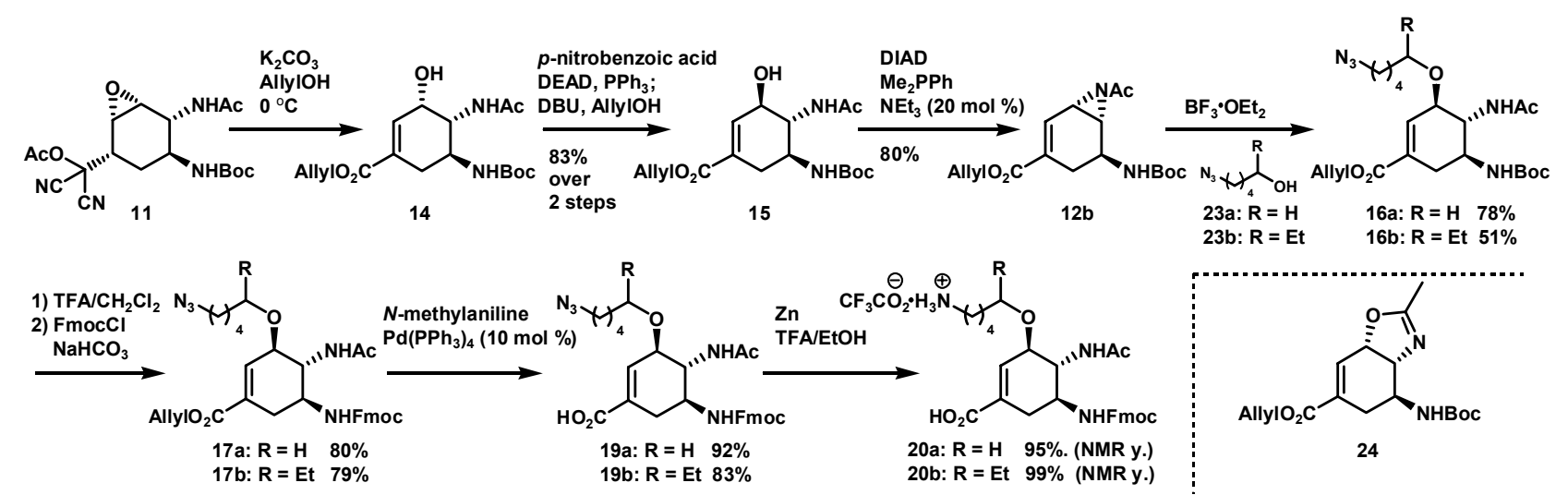

Scheme 2. Synthesis of Tamiflu core $\mathbf{2 0}$ 
Table 1. Examined reduction conditions for $\mathbf{1 7 a}$.

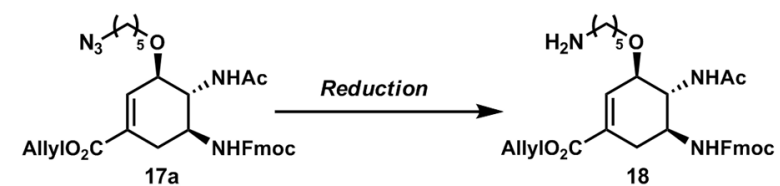

\begin{tabular}{|c|c|c|}
\hline entry & conditions & results \\
\hline 1 & $\begin{array}{l}\mathrm{PPh}_{3}(1.2 \mathrm{eq}), \mathrm{H}_{2} \mathrm{O} / \mathrm{THF}(10 \% \mathrm{v} / \mathrm{v}) \text {, } \\
\mathrm{rt} \text { to } 50{ }^{\circ} \mathrm{C}\end{array}$ & No Reaction \\
\hline 2 & $\begin{array}{l}n-\mathrm{Bu}_{3} \mathrm{P}(2.0 \mathrm{eq}), \mathrm{H}_{2} \mathrm{O} / \mathrm{THF}(10 \% \mathrm{v} / \mathrm{v}) \\
4{ }^{\circ} \mathrm{C} \text { to rt }\end{array}$ & Complex mixture \\
\hline 3 & $\begin{array}{l}\text { Lindlar catalyst }(50 \% \mathrm{w} / \mathrm{w}), \\
\mathrm{H}_{2}(1 \mathrm{~atm}), \mathrm{EtOH}, \mathrm{rt}\end{array}$ & No $\mathbf{1 8}^{c}$ \\
\hline 4 & $\begin{array}{l}\text { Lindlar catalyst }(50 \% \mathrm{w} / \mathrm{w}), \\
\mathrm{H}_{2}(1 \mathrm{~atm}), \text { EtOAc, } \mathrm{rt}\end{array}$ & No Reaction \\
\hline 5 & $\begin{array}{l}\mathrm{NaBH}_{4}(2 \mathrm{eq}), \mathrm{CoCl}_{2}(2 \mathrm{eq}), \\
\mathrm{H}_{2} \mathrm{O} / \mathrm{THF}(50 \% \mathrm{v} / \mathrm{v})\end{array}$ & No Reaction \\
\hline 6 & $\mathrm{SnCl}_{2}(2 \mathrm{eq}), \mathrm{MeOH}, \mathrm{rt}$ & Complex mixture \\
\hline 7 & $\mathrm{Zn}^{a}(100 \mathrm{eq}), \mathrm{AcOH}, \mathrm{rt}$ & 18 у. $50 \%(\mathrm{NMR})$ \\
\hline 8 & $\mathrm{Zn}^{b}(100 \mathrm{eq}), \mathrm{TFA} / \mathrm{EtOH}(20 \%, \mathrm{v} / \mathrm{v}), \mathrm{rt}$ & 18 y. $81 \%(N M R$ y \\
\hline
\end{tabular}

${ }^{a}$ Zinc pre-activated with $1 \mathrm{~N} \mathrm{HCl} \mathrm{aq.}{ }^{b}$ Zinc pre-activated with 1,2-dibromoethane. ${ }^{c}$ Mass spectral analysis of the reaction mixture suggested that the allyl moiety was hydrogenated with the azide remained intact.

TFA/EtOH solvent. Amine $\mathbf{1 8}$ was roughly isolated in ca $70 \%$ yield under these optimized conditions. Subsequent allyl ester cleavage using Pd catalysts, however, was not successful. ${ }^{7}$

Therefore, allyl ester cleavage of $\mathbf{1 7}$ was next investigated (Scheme 2). The conversion proceeded in high yield (19a; 92\% $19 \mathrm{~b} ; 83 \%)$ in the presence of $10 \mathrm{~mol} \mathrm{\%}$ of $\mathrm{Pd}\left(\mathrm{PPh}_{3}\right)_{4}$ and $N$ methylaniline. Reduction of the azide in $\mathbf{1 9}$ under the abovementioned optimized conditions afforded $\mathbf{2 0}$ in excellent yield (20a: 95\%, 20b: 99\%, NMR y.). Because 20 is water soluble and highly polar, they were only partially purified by filtration through Celite to eliminate the excess zinc and resulting zinc salts.

The final step of the synthesis was linking $\mathbf{2 0}$ to the chromatographic resin, Affi-Gel $10^{\circledR}(\mathbf{2 1}$; Scheme 3$)$. The coupling reaction was performed using 20a under slightly basic conditions $(\mathrm{pH} 8)$ in the presence of $\mathrm{Et}_{3} \mathrm{~N}$ in $\mathrm{MeOH}$ at room temperature for $1 \mathrm{~h}$. After the coupling reaction, the resin was separated by filtration and washed with $\mathrm{MeOH}{ }^{8}$ Finally, removal of the Fmoc group and blocking of the remaining activated ester on the resin were conducted simultaneously using excess piperidine (in a volume equal to that of the undried resin) in DMF at room temperature for $24 \mathrm{~h}$. ${ }^{9}$ Complete removal of the Fmoc group was confirmed by quantitative NMR analysis of 22, a byproduct in the Fmoc cleavage reaction, which was recovered in the solution phase. 3b was also synthesized following almost the same procedure (see experimental sections for the details).

We then assessed the binding affinity of synthesized conjugate 3 to neuraminidase. The criterion in this preliminary binding study was whether NA binds to the resin. A control resin was prepared by reacting piperidine, instead of 20, with Affi-Gel $10^{\mathbb{R}}$. Recombinant Influenza A virus H1N1 neuraminidase (rvH1N1NA) and $50 \mu \mathrm{L}$ of each $40 \%$ resin (3a or $\mathbf{3 b}$ or control resin) were mixed and incubated in a buffer for $2 \mathrm{~h}$. After wash-

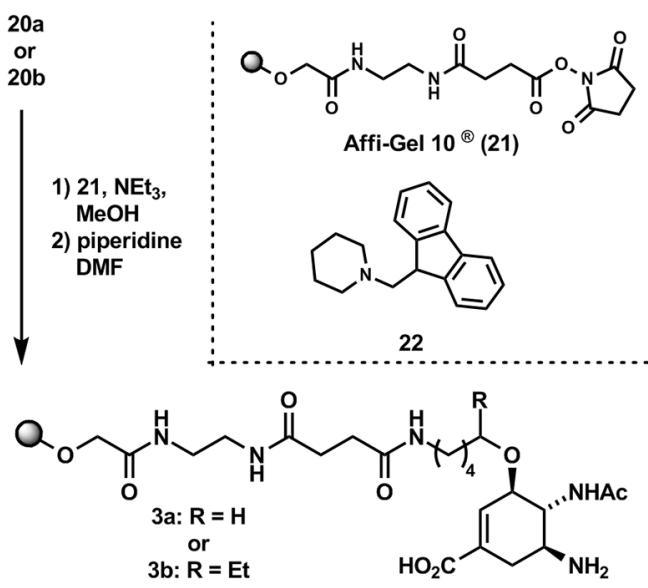

Scheme 3. Coupling of Tamiflu core 20 and Affi-gel $10^{\circledR}$

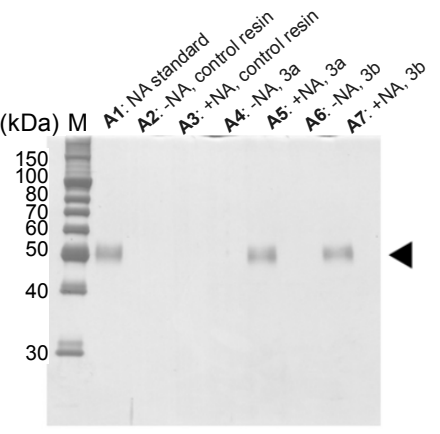

(A) Silver staining

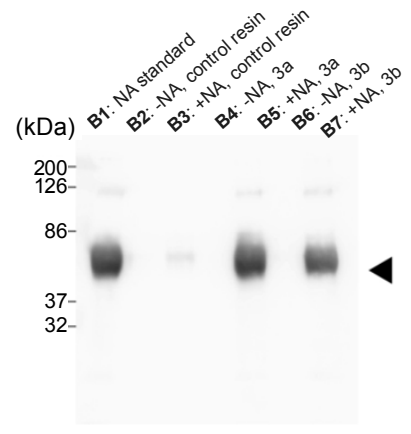

(B) Western blotting
Figure 3. Binding of neuraminidase (rvH1N1NA) to resin-conjugated Tamiflu analogs $\mathbf{3 a}$ and $\mathbf{3 b}$. Binding assay of rvH1N1NA was performed for 3. The eluted protein was analyzed by SDS-PAGE and was detected by (A) silver staining and (B) Western blotting. A molecular weight of rvH1N1NA is $48 \mathrm{kDa}$, and it migrates as a $57 \mathrm{kDa}$ band in SDS-PAGE. The position of rvH1N1NA was marked by the arrowhead. rvH1N1NA (lanes 3, 5, and 7) or buffer (lanes 2, 4, and 6) was applied for control resin (lanes 2, and 3) or 3a (lanes 4 and 5) or $\mathbf{3 b}$ (lanes 6 and 7). M, molecular weight marker; lane 1, rvH1N1NA standard $(0.25 \mu \mathrm{g})$.

ing the resin with buffer, the resin was resuspended in SDSsample buffer and was boiled for 2 - $3 \mathrm{~min}$. The supernatant was subjected to electrophoresis on SDS-10\% polyacrylamide gel, and was visualized with (a) silver-staining and (b) Western blotting. rvH1N1NA was detected in the bound fraction at the expected position on the gel when rvH1N1NA was mixed with resinconjugated Tamiflu analogs $\mathbf{3 a}$ and $\mathbf{3 b}$ (Fig. 3, lanes 5 and 7). rvH1N1NA was not detected in other lanes on the gel. These results revealed that Tamiflu analogs $\mathbf{3 a}$ and $\mathbf{3 b}$ have a binding activity to rvH1N1NA. It was also confirmed that $\mathbf{3 a}$ and $\mathbf{3 b}$ have almost similar binding affinity to NA.

In conclusion, we synthesized immobilized Tamiflu analogs on resin by modifying our original synthetic route of Tamiflu. ${ }^{\text {In }}$ This study demonstrated the highly flexible nature of our synthetic route. The prepared resins bound to NA, the main target of Tamiflu. Studies are ongoing to identify Tamiflu's possible endogenous target biomolecules in vertebrates using affinity chro- 
matography of the synthesized resins.

Acknowledgments. Financial support was provided by The Uehara Memorial Foundation and Grant-in-Aid for Scientific Research (S) from JSPS. Mr. Liang Yin is deeply acknowledged for synthesizing 7 .

\section{References}

1. (a) Kim, C. U.; Lew, W.; Williams, M. A.; Liu, H.; Zhang, L.; Swaminathan, S.; Bischofberger, N.; Chen, M. S.; Mendel, D. B.; Tai, C. Y.; Laver, W. G.; Stevens, R. C. J. Am. Chem. Soc. 1997, 119, 681. For studies on the synthesis of Tamiflu, see: (b) Yueng, Y.-Y.; Hong, S.; Corey, E. J. J. Am. Chem. Soc. 2006, 128, 6310. (c) Fukuta, Y.; Mita, T.; Fukuda, N.; Kanai, M.; Shibasaki, M. J. Am. Chem. Soc. 2006, 128, 6312. (d) Cong, X.; Yao, Z.-J. J. Org. Chem. 2006, 71, 5365. (e) Mita, T.; Fukuda, N.; Kanai, M.; Shibasaki, M. Org. Lett. 2007, 9, 259. (f) Yamatsugu, K.; Kamijo, S.; Suto, Y.; Kanai, M.; Shibasaki, M. Tetrahedron Lett. 2007, 48, 1403. (g) Bromfield, K. M.; Graden, H.; Hagberg, D. P.; Olsson, T.; Kann, N. Chem. Commun. 2007, 3183. (h) Satoh, N.; Akiba, T.; Yokoshima, S.; Fukuyama, T. Angew. Chem., Int. Ed. 2007, 46, 5734. (i) Shie, J.-J.; Fang, J.-M.; Wang, S.-Y.; Tsai, K.-C.; Cheng, Y.-S. E.; Yang, A.-S.; Su, C.-Y.; Wong, C.-H. J. Am. Chem. Soc. 2007, 129, 11892. (j) Kipassa, N. T.; Okamura, H.; Kina, K.; Hamasa, T.; Iwagawa, T. Org. Lett. 2008, 10, 815. (k) Trost, B. M.; Zhang, T. Angew. Chem., Int. Ed. 2008, 47, 3759. (1) Zutter, U.; Iding, H.; Spurr, P.; Wirz, B. J. Org. Chem. 2008, 73, 4895. (m) Shie, J.-J.; Fang, J.-M.; Wong, C.-H. Angew. Chem., Int. Ed. 2008, 47, 5788. (n) Yamatsugu, K.; Yin, L.; Kamijo, S.; Kimura, Y.; Kanai, M.; Shibasaki, M. Angew. Chem., Int. Ed. 2009, 48, 1070. (o) Matveenko, M.; Willis, A. C.; Banwell, M. G. Tetrahedron Lett. 2008, 49, 7018. (p) Ishikawa, H.; Suzuki, T.; Hayashi, Y. Angew. Chem., Int. Ed. 2009, 48, 1304. (q) Mandai, T.; Oshitari, T. Synlett 2009, 783. (r) Oshitari, T.; Mandai, T. Synlett 2009, 787. (s) Satoh, N.; Akiba, T.; Yokoshima, S.; Fukuyama, T. Tetrahedron 2009, 65, 3239. (t) Nie, L.-D.; Ko, X.-X.; Ko, K. H.; Lu,W.-D. J. Org. Chem. 2009, 74, 3970. (u) Sullivan, B.; Carrera, I.; Drouin, M.; Hudlicky, T. Angew. Chem., Int. Ed. 2009, 48, 4229. (v) Hai, S.; Ying-Jie, L.; Yu-Lin, W.; Yikang, W. Synlett 2009, 2473. (w) Yamatsugu, K.; Kanai, M.; Shibasaki, M. Tetrahedron 2009, 65, 6017; For reviews on the synthesis of Tamiflu, see: (x) Farina, N.; Brown, J. D. Angew. Chem., Int. Ed. 2006, 45, 7300. (y) Shibasaki, M.; Kanai, M. Eur. J. Org. Chem. 2008, 1839. (z) Magano, J. Chem. Rev. 2009, 109, 4398

2. (a) Izumi, Y.; Tokuda, K.; O’Dell, K. A.; Zorumski, C. F.; Narahashi, T. Neurosci. Lett. 2007, 426, 54. (b) Ishii, K.; Hamamoto, H.; Sasaki, T.; Ikegaya, Y.; Yamatsugu, K.; Kanai, M.; Shibasaki, M.; Sekimizu, K. Drug Discov. Ther. 2008, 2, 24. (c) Ose, A.; Kusuhara, H.; Yamatsugu, K.; Kanai, M.; Shibasaki, M.; Takuya, F.; Yamamoto, A.; Sugiyama, Y. Drug Metab. Dispos. 2008, 36, 427. (d) Morita, M.; Sone, T.; Yamatsugu, K.; Sohotome, Y.; Matsunaga, S.; Kanai, M.; Watanabe, Y.; Shibasaki, M. Bioorg. Med. Chem. Lett. 2008, 18, 600. (e) Konno, F.; Arai, T.; Zhang, M.-R.; Hatori, A.; Yamamoto, K.; Ogawa, M.; Ito, G.; Odawara, C.; Yamasaki, T.; Kato, K.; Suzuki, K. Bioorg. Med. Chem. Lett. 2008,
18, 1260. (f) Usami, A.; Sasaki, T.; Satoh, N.; Akiba, S.; Yokoshima, S.; Fukuyama, T.; Yamatsugu, K.; Kanai, M.; Shibasaki, M.; Matsuki, N.; Ikegaya, Y. J. Pharamacol. Sci. 2008, 106, 659. (g) Ono, H.; Nagano, Y.; Matsunami, N.; Sugiyama, S.; Yamamoto, S.; Tanabe, M. Biol. Pharm. Bull. 2008, 31, 638. (h) Yoshino, T.; Nishijima, K.; Shioda, K.; Yui, K.; Kato, S. Neurosci. Lett. 2008, 438, 67. (i) Hata, K.; Koseki, K.; Yamaguchi, K.; Moriya, S.; Suzuki, Y.; Yingsakmongkon, S.; Hirai, G.; Sodeoka, M.; von Itzstein, M.; Miyagi, T. Antimicrob. Agents Chemother. 2008, 52, 3484. (j) Jhee, S. S.; Yen, M.; Ershefsky, L.; Leibowitz, M.; Schulte, M.; Kaeser, B.; Boak, L.; Patel, A.; Hoffmann, G.; Prinssen, E. P.; Rayner, C. R. Antimicrob. Agents Chemother. 2008, 52, 3678. (k) Toovy, S.; Rayner, C.; Prinssen, E.; Chu, T.; Donner, B.; Thakrar, B.; Dutkowski, R.; Hoffmann, G.; Breidenbach, A.; Lindemann, L.; Carey, E.; Boak, L; Gieschke, R.; Sachs, S.; Solsky, J.; Small, I.; Reddy, D. Drug Safety 2008, 31, 1097. (1) Ose, A.; Ito, M.; Kusuhara, H.; Yamatsugu, K.; Kanai, M.; Shibasaki, M.; Hosokawa, M.; Schuetz, J. D.; Sugiyama, Y. Drug Metab. Dispos. 2009, 37, 315. (m) Hatori A.; Arai, T.; Yamamoto, K.; Yamasaki, T.; Kawamura, K.; Yul. J.; Konno, F.; Nakao, R.; Suzuki, K.; Zhang, M. -R. Nucl. Med. Biol. 2009, 36, 47. (n) Izumi, Y.; Tokuda, K.; O’Dell, K. A.; Zorumski, C. F.; Narahashi, T. Hum. Exp. Toxicol. 2009, 27, 911. (o) Arai, T.; Konno, F.; Ogawa, M.; Zhang, M. R.; Suzuki, K. J. Labelled Compd. Radiopharm. 2009, 52, 350. (p) Hoffmann, G.; Funk, C.; Fowler, S.; Otteneder, M. B.; Breidenbach, A.; Rayner, C. R.; Chu, T.; Prinssen, E. P. Antimicrob. Agents Chemother. 2009, 53, 4753. (q) Oshima, S.; Nemoto, E.; Kuramochi, M.; Saitoh, Y.; Kobayshi, D. J. Pharm. Pharmacol. 2009, 61, 1397. (r) According to the Ministry of Health, Labor, and Welfare of Japan, there is no relationship between Tamiflu administration and abnormal behaviors based on animal experiments performed by the Chugai Pharmaceutical Company, which sells Tamiflu in Japan. For details, see http://www.mhlw.go.jp/ shingi/2007/12/s1210-6.html, http://www.chugai-pharm.co.jp/ $\mathrm{html} / \mathrm{info} / 071210 . \mathrm{html}$. (s) For our original communication of this full article, see: Kimura, Y.; Yamatsugu, K.; Kanai, M.; Echigo, N.; Kuzuhara, T.; Shibasaki, M. Tetrahedron Lett. 2009, 50, 3205.

3. To a dried flask, zinc $(30 \mathrm{~g})$, THF $(50 \mathrm{~mL})$ 1,2-dibromoethane $(1.0 \mathrm{~mL})$ was added and and the mixture was stirred at $50{ }^{\circ} \mathrm{C}$ for $2 \mathrm{~h}$. Zinc was separated by filtration and washed with THF. Remaining THF on zinc was removed under reduced pressure.

4. (a) Rusell, R. J.; Haire, L. F.; Stevens, D. J.; Collins, P. J.; Lin, Y. P.; Blackburn, G. M.; Hay, A. J.; Gamblin, S. J.; Skehel, J. J. Nature 2006, 443, 45. (b) Collins, P. J.; Haire, L. F.; Lin, Y. P.; Liu, J.; Rusell, R. J.; Walker, P. A.; Skehel, J. J.; Martin, S. R.; Hay, A. J.; Gamblin, S. J. Nature 2008, 453, 1258.

5. For the synthesis of 5-azidopentan-1-ol (23a), see: Gracias, V.; Frank, K. E.; Milligan, G. L.; Aube, J. Tetrahedron 1997, 53, 16241.

6. The reaction with 4 equiv or 10 equiv of alcohol 23a gave low yields (approximately $20 \%$ and $40 \%$, respectively) of ether $\mathbf{1 6 a}$.

7. The allyl ester removal from 18 using catalytic $\mathrm{Pd}\left(\mathrm{PPh}_{3}\right)_{4}$ afforded a complex mixture.

8. Approximately $40 \%$ of unreacted 20a was recovered based on NMR analysis of the combined solution phases.

9. Ullrich, T.; Ghobrial, M.; Peters, C.; Billich, A.; Guerini, D.; Nussbaumer, P. Chem. Med. Chem. 2007, 3, 356. 